\title{
The wages of whiteness in the absence of wages: racial capitalism, reactionary intercommunalism and the rise of Trumpism
}

\begin{abstract}
:
In November 1970 Black Panther Party leader Huey P. Newton gave a lecture at Boston College where he introduced his theory of intercommunalism. Newton re-articulated Marxist theories of imperialism through the lens of the Black liberation struggle and argued that imperialism had entered a new phase called 'reactionary intercommunalism'. Newton's theory of intercommunalism offers nothing less than a proto-theorization of what we have come to call neo-liberal globalization and its effects on what W.E.B. Du Bois had seen as the racialization of modern imperialism. Due to the initial historical dismissal of the Black Panther Party's political legacy, Newton's thought has largely been neglected for the past forty years. This paper revisits Newton's theory of intercommunalism, with the aim of achieving some form of epistemic justice for his thought, but also to highlight how Newton's recasting of imperialism as reactionary intercommunalism provides critical insight into the rise of Trumpism in the US.
\end{abstract}

Keywords: Black Panthers, Imperialism, Globalization, Neo-liberalism, Whiteness, Intercommunalism, Trumpism.

Introduction: What's Marxism got to do with it?

Huey P Newton: So tonight I think I have covered some of what I had to say. I will allow you to talk. We will have a question and answer session.

Audience Question: The first thing I want to say is fuck Karl Marx, fuck Lenin, and speak about racism. Because racism is what started the Black Panther Party. Racism is the reason we're in the predicament that we're in now and I don't think you can relate something that's written in the $19^{\text {th }}$ century to what is taking place now... 1

In November 1970, Black Panther Party (BPP) leader Huey P. Newton gave a lecture at Boston College where he introduced his theory of intercommunalism. Having been significantly weakened by the violent 
effects of the FBI's Counter Intelligence Program against Black radicalism in the preceding couple of years, Newton used the lecture to shift the BPP's ideology away from a perception of armed struggle against the US State and towards the idea of a wider project of creating anti-racist and antiimperialist solidarity. ${ }^{2}$ Articulated in the midst of revolutionary struggle at home in the US, and beyond in the Third World, intercommunalism saw Newton narrate anti-Black racism through the theory of imperialism. Not all of Newton's audience that day, and in the months that followed, were enamoured with a theory that cast Black liberation within Marxist terminology. ${ }^{3}$ However, upon closer examination it becomes clear that Newton did not simply subordinate Black liberation to the tenets of Marxism, but rather re-articulated Marxist theories of imperialism through the Black experience. Moreover, Newton's theorization of what he saw as 'reactionary intercommunalism' marks nothing less than a fundamental change in the nature of imperialism. Unfortunately, posterity has been unkind to Newton's thought, which has largely been ignored for the last forty years. Even with the recent historical reappraisal of the Black Power movement, and specifically the BPP"s political legacy ${ }^{4}$, Newton's thought has generally been neglected. ${ }^{5}$ This paper seeks to revisit Newton's ideas about intercommunalism to not only achieve some form of epistemic justice for his thought, but also to highlight how Newton's recasting of imperialism as 'reactionary intercommunalism' provides critical insight into the rise of Trumpism's xenophobic and racist nationalism.

To achieve this, this article is made up of four parts. The first part narrates W.E.B. Du Bois' theorisation of the link between imperialism and the wages of whiteness. The second and third parts outline how Newton's theorisation of reactionary intercommunalism reinterprets Du Bois' theorization of the link between racial capitalism and imperialism for the neo-liberal era. This centres on Newton's argument that reactionary intercommunalism would disrupt the racial compact of the post-war economy and lead to racial conflict rather than solidarity. The fourth section attempts to show how Newton's predictions about reactionary intercommunalism have largely 
come to fruition and laid the grounds for the emergence of 'Trumpism' in the US. This has led to the contemporary evocation of what I call 'the wages of whiteness in the absence of wages' and hence the emboldening of racism, xenophobia and populism in the US, in reaction to the effects of neo-liberal globalization.

\section{Racial Capitalism: Imperialism and the Souls of White Folks}

The classic theorization of imperialism has a European and Russian lineage. Neo-Marxist's such as Luxemburg and Lenin theoretically expanded Hobson's thesis that it was the maldistribution of income within Europe that was key to understanding colonial expansion beyond Europe. ${ }^{6}$ In identifying this relationship these neo-Marxist authors sought to expand what they perceived as Marx's own limited offerings on imperialism. ${ }^{7}$ But this lineage of the classic theorisations of imperialism can also be traced back through the work of African American sociologist W.E.B. Du Bois. Unlike his European luminaries, Du Bois places the concept of racial capitalism at the heart of his theory of imperialism. ${ }^{8}$ This is evident in the Souls of Black Folk, where Du Bois famously declares that 'the problem of the twentieth century is the problem of the colour line." 9 The colour line was the imperial meridian along which Western imperialism had divided the world into blocs of light and dark races for the basis of capitalist exploitation.

In an essay entitled 'The African Roots of the War', published in 1915, Du Bois pre-empted many of Lenin's core arguments about the nature of imperialism. Here Du Bois located the roots of World War One in the emergence of monopoly capitalism and liberal democracy in the West and the creation of large amounts of surplus capital, which needed outlets beyond Europe and North America. Some of this surplus capital had been used to buy off the West's working classes, turning them into an 'aristocracy of labour' and aligning their material interests with imperial plunder in the 
'darker nations of the world.' Du Bois concluded that the onset of World War One centred on the 'jealousies engendered' between 'armed national associations of labour and capital' over the 'division of spoils of worlddominion'. These associations were now fighting, and drawing in their colonial populations into such a conflict, to enlarge 'their respective shares' not in Europe 'but in Asia, and particularly in Africa.' 10

However, Du Bois' theorisation of imperialism did not merely anticipate Lenin's work, but also offered an additional explanation of how racial identity and racism culturally underpinned the entire imperial order. ${ }^{11} \mathrm{Du}$ Bois linked imperialism with the establishment of a racialized global division of labour and the emergence of the early tenets of welfare capitalism in Europe and the US. This system divided humanity across the colour line and underscored the Western nation state and its citizens with an identity of 'whiteness'. This soul of whiteness, Du Bois argued, was a 'modern thing' directly related to imperial exploitation of the 'darker nations' across the nineteenth and early twentieth centuries. The white identity valorised everything white whilst taking 'everything mean, bad, blundering cheating and dishonourable' to be non-white. As Du Bois quipped, the white world was certain that '...a bad taste was "brown"' and that 'the devil was "black.",12

Western imperialism's economic and cultural order in turn allowed its elites to provide their national populations with a 'wage of whiteness.' 13 These imperial wages of whiteness allowed the West's capitalist elite to provide both a material, and public and psychological wage for the West's working and middle classes through an imperial subdivision of labour and labour conditions:

The day of the very rich is drawing to a close, so far as individual white nations are concerned. But there is a loophole. There is a chance for exploitation on an immense scale for inordinate profit, not simply to the very rich. But to the middle class and to the labourers. 
This chance lies in the exploitation of darker peoples. It is here that the golden hand beckons. Here are no labour unions or votes or questioning onlookers or inconvenient consciences. These men may be used down to the very bone, shot and maimed in "punitive" expeditions when they revolt. In these dark lands "industrial development" may repeat in exaggerated form every horror of the industrial history of Europe, from slavery and rape to disease and maiming, with only one test of success, - dividends! ${ }^{14}$

Du Bois' theorisation of imperialism pivoted on a direct link between the formation of modern racism, super-exploitation outside of the West and the founding of the democratic capitalist state in the West. Not only was labour in Africa and Asia 'kept cheap and helpless because the white world despises darkies,' but the 'high wages' of nations such as Britain and the US were the 'skilful manipulated result of the slavery of Africa and the peonage of Asia.' These wages of whiteness provided the ideological and material ballast for Western imperial expansion, but also infected the Western labour movement. Du Bois noted how in the face of economic and democratic concessions granted by capital and bourgeois nation states to their working classes, the Western labour movement's idea of socialism all but read nonwhites, both at home and aborad, out of the 'kingdom of industrial justice'. ${ }^{15} \mathrm{Du}$ Bois' theorisation of imperialism thus demanded an understanding of the cultural order that racialized the division of labour and allowed class justice to be tied solely to the West and its white subjects.

The idea that democratic capitalism in the West, and indeed socialism in the West, was tied to a cultural order of racism and imperial superexploitation would find resonance with mid twentieth century anti-colonial thinkers such as Frantz Fanon and dependency theory's critique of the economic underdevelopment of the Third World. ${ }^{16}$ Gunnar Myrdal, for example, argued that the Western welfare state rather than promoting international justice was actually: 
'...nationalistic, indeed very much more so than a laissez faire type of State would be. Thus tremendous forces of vested interests, often spread out among board layers of the citizens, are so created that they can be mobilized to abstain from polices for underdeveloped countries... On this point the people are reactionaries. ${ }^{17}$

What united these critiques was the belief that the material benefits of imperialism, and the racialized cultural order that underpinned such a system, prevented the European and North American masses from realising Marx and Engel's call for the workers of the world to unite. What I want to suggest in the next two sections is that Huey P. Newton's theory of reactionary intercommunalism essentially highlights how the effects of neoglobalization would disrupt the wages of whiteness but still end-up subdividing the humanity across racial dimensions long engrained by imperialism.

\section{Reactionary intercommunalism: the new imperialism}

Huey P. Newton's formulation of what he called 'reactionary intercommunalism' is essentially a reflection on the reality of post-war US hegemony and its transformation of the nature of imperialism. Newton argued that the macroeconomic changes of World War II, such as the rapid decolonization of European empires and the restructuring of the global economy at Bretton Woods, had rendered the US an unrivalled global hegemon. Moreover, the global power and reach of the US military, mass media and its corporate and financial capital had now turned the US from a nation state into an unprecedented form of imperial empire:

The United States was no longer a nation. It was something else; it was more than a nation. It had not only expanded its territorial boundaries, but it had expanded all of its controls as well. We called it an empire. Now at one time the world had an empire in which the conditions of rule were different the Roman Empire. The difference 
between the Roman and the American empires is that other nations were able to exist external to and independent of the Roman Empire because their means of exploration, conquest, and control were all relatively limited. But when we say "empire" today, we mean precisely what we say. An empire is a nation-state that has transformed itself into a power controlling all the world's lands and people. ${ }^{18}$

However, Newton outlined that US empire heralded a new phase of imperialism, which he called 'reactionary intercommunalism', because the rationale of such imperialism sought to integrate the world 'into one community' of capitalist production and consumption ${ }^{19}$ This new phase of imperialism would blur the geo-politics of Du Bois' colour line in order to perpetuate corporate capitalist exploitation and avoid the pitfalls of capitalist over-production. Newton detailed how this had changed the imperial problematic from the 'land question', which centred on territorial acquisition, occupation and resource extraction, to the 'technology question', which centred on the expansion of markets, labour and consumption. Reactionary intercommunalism therefore meant that the 'ruling circle' of the US government and Western corporate and financial capital nominally pursued a path of 'peaceful co-optation' rather than formal imperial occupation to achieve imperial rule. ${ }^{20}$

This is what the concept of "peaceful coexistence" means: peaceful co-optation... The people of the oppressed territories might fight on the land question and die over the land question. But for the United States, it is the technology question, and the consumption of the goods that the technology produces! ${ }^{21}$

Reactionary intercommunalism, Newton contended, would see the Second and Third World also become a site of capitalist production, technology and forms of consumption, but also with an increased rate of super-exploitation. This centered on western based multi-national corporations penetrating 
these regions in order to create a global commodity and consumption chain. This disarticulated form of Fordism ${ }^{22}$ would see 'advanced technologies transplanted into these areas' but still under the control of Western interests. ${ }^{23}$ The result would be a new global geography of industrial production that would eradicate socialist alternatives to capitalist market societies:

Those who support the so-called socialist states will begin to be swayed by the introduction of a U.S. consumer market into their socialist countries. This becomes an even greater problem, because reactionary intercommunalism would then infect the very people of that part of the world... It is a technology people question, and that is why the United States will fight hard for an introduction to new markets abroad . ${ }^{24}$

This process would see 'growth without development' with increased capital flows from the Second and Third World back into the First. A regime supported by self-enriching 'comprador agents' in nation states across Africa, Asia and Latin America, who would bow to the power and ideology of empire and readily oppress and exploit their own people in order to secure their own position and wealth. ${ }^{25}$

Newton concluded that the irony of reactionary intercommunalism was that the global non-state envisioned by Communism had to all intents and purposes '...already been accomplished, but it is reactionary.' ${ }^{26}$ This new phase of imperialism meant that all of the world's nation states had become interconnected and under siege by the ruling circle of global capital and capitalist ideology. This had in turn reduced humanity to a collection of communities (Black, Chinese, Korean) who, whilst sharing different material and cultural experiences, were united by the reality of the full spectrum dominance of capital:

There is an undeniable interconnection to everything among all the territories in the world. That is why we say that there are no longer 
nations; there are only communities under siege by the reactionaries. This is where we get the term reactionary intercommunalism. ${ }^{27}$

\section{The Declining Wages of Whiteness}

Perhaps the most prescient aspect of Newton's theorization of reactionary intercommunalism was his belief that the fundamental change in the nature of imperialism would also create a fundamental change in the nature of the wages of whiteness. Newton argued that the nature of post-war capitalism would be disrupted due to the effects of reactionary intercommunalism's disarticulated Fordism and increased technological advancement. Moreover, Newton outlined how technological innovation (automation, robotics, cybernetics) combined with an increasing global labour arbitrage, would eradicate the need for expensive wageworkers in the First World. This would see the increase of the lumpen-proletariat and the decrease of the proletariat' and the likely dismantling of the welfare state as ruling circles sought to maximise profits and their share of income:

Technological development creates a large middle class, and the number of workers increases also. The workers are paid a good deal and get many comforts. But the ruling class is still only interested in itself. They might make certain compromises and give a little -as a matter of fact, the ruling circle has even developed something of a social structure or welfare state to keep the opposition down- but as technology develops, the need for workers decreases. ${ }^{28}$

Newton believed that the breaking of the post-war compact between capital and labour would have consequent effects for the wages of whiteness. The US adaption of welfare capitalism, found in the New Deal for example, had propagated ideas such as full employment. However, this process had left the racial segregation and oppression, which had defined the US state since its inception, relatively untouched. Newton foresaw that reactionary intercommunalism would see states and corporations break both the economic and racial compacts that defined the post-war era. This would not 
end racial capitalism, within the US, but rather see the boomeranging of conditions and practices found in the darker nations of the Third World (and ghettos of the US), such as deindustrialisation, structural unemployment, state retrenchment and super-exploitation, back into the general (white) population of the US and rest of the First World:

Reactionary intercommunalism perceiving the interrelationship of all natural phenomena, including all human beings, seizes upon the phenomena in an attempt to distort the balance in its favor. This exploitation has led to enormous profits and power in the short run. But in a split second, historically, the super industrial engines of the imperialist, reactionary intercommunalists have come to grief, and even the populations of the Anglo-American Empire itself are in the process of being "nativized" and pauperized... ${ }^{29}$

The effects of reactionary intercommunalism would create a fundamental change in the nature of the wages of whiteness through reducing white members of the working class to the precarious labour market conditions of their black counterparts. ${ }^{30}$ However, despite reactionary intercommunalism bringing white and non-white labour into similar 'objective class' positions, Newton didn't believe that this would organically yield an end to racism or create solidarity between white and non-white labour in the US. Rather, Newton underlined how the former would increasingly fail to see the 'objective enemy' of the ruling circle and instead become 'subjective enemies' of their Black counterparts:

Here in America racism is rampant and we will have to do something about that...increasingly our objective class brothers act in a way, which will harm Black people, in other words they are subjectively our enemy. And I would use the hard-hat as an example. The hardhats are exploited, they're becoming seasonally employed in other words, they're well on their way to becoming unemployables and instead of blaming their master, they blame us for it. ${ }^{31}$ 
Newton detected this failure of to see objective class relationships not only amongst white members of the working class, but also increasingly across white members of the middle class. This centred on Newton's belief that reactionary intercommunalism would increasingly enrich the ruling circle and create a plutocracy that curtailed the economic security and political influence of even the formerly prosperous white middle class:

There are very few controllers even in the white middle class. They can barely keep their heads above water, they are paying all the bills, living hand-to-mouth, and they have the extra expense of refusing to live like Black people, you see. So they are not really controlling anything; they are controlled. ${ }^{32}$

What Newton's work prefigures here is that the very macroeconomic changes associated with reactionary intercommunalism, such as increased proletarianisation in the Third World and deindustrialisation and the increasing lumpen-proletarianization in the First World, would inherently alter the wages of whiteness Du Bois associated with imperialism at the start of the twentieth century. Although the racial segregation of post-war capitalism carried on the process of disuniting the revolutionary potential of united non-white and white labour, both within and beyond the US, Newton understood that reactionary intercommunalism would herald the reconfiguration of the material reality of white supremacy that had underpinned US society since its formation. This would see the ruling circle enrich themselves through technological innovation and the expansion of the geography of capitalist production and enact processes that would in turn cripple the economic and political power of the white members of the working and middle classes.

Newton also argued that rather than eradicating racial capitalism, reactionary intercommunalism's disruption of the racialized foundations of US welfare capitalism would serve to perpetuate forms of racial disunity and 
foreclose the emergence of a racially unified revolutionary subject amongst the US masses. The history of racialized subject positions that Du Bois narrated at the start of the twentieth century would not easily be discarded even in the midst of economic processes that increasingly aligned the real interests of white citizens with their non-white counterparts (both at home and abroad). Even with the disappearance of the perceived privileges of the wages of whiteness, such as stable employment and political influence, the politics of race would continue to inform inter-class relations. As the impact of reactionary intercommunalism took effect, and the wages of whiteness became ever absent, Newton believed that communities in the US would often 'feel more and more that it's a race contradiction rather that a class contradiction.' 33

Newton's theorization of imperialism's evolution towards reactionary intercommunalism has proven eerily prescient and is best read as a prototheorization of what we have come to call neo-liberal globalization. Newton's forewarning that the interests of corporate and financial capital, technological advancement and a new geography of industrial production would lead to deindustrialization, precarious employment, and increasing inequality in the First World, is seemingly only bettered by his analysis of how Third World socialism would be defeated through Western neoimperialism, non-white elite enrichment and the expansion of capitalist forms of production and super-exploitation amongst the wretched of the earth. ${ }^{34}$ As explored in greater detail in the next section, Newton's prescience in regards to the effects of neo-liberal globalization on the US economy alone provides fertile ground for a return to Newton's thought. However, Newton's insight into the diminishing wages of whiteness provides even greater insight into the political effects of neo-liberal globalization in nations such as the US. As I argue below, the emergence of 'Trumpism' is best read through Newton's theorization of neo-liberalism's diminishing wages of whiteness.

Trumpism: the wages of whiteness in the absence of wages 
'We will no longer surrender this country, or its people, to the false song of globalism'35

In November 2016 Donald Trump was elected as the 45th US President, with the mandate to 'Make America Great Again’ (MAGA). This was achieved on the back of a white nationalist and xenophobic policy platform: that scapegoated other nations (namely China and Mexico) for US unemployment and deindustrialization; blamed minority communities and immigrants for crime and welfare abuse; branded Muslims as an internal and external security threat; and demonized social justice movements founded on issues of race such as the Black Lives Matter movement. This nationalist and racist platform was in turn entwined with an economic policy platform that addressed the effects of neo-liberalism. This was reflected in Trump's promise to reverse deindustrialization through amending or rejecting trade deals, such as North American Free Trade Agreement (NAFTA) and the Trans-Pacific Partnership (TPP), using tax penalties to repatriate outsourced jobs and deporting illegal immigrants. All on the supposed basis of creating jobs, driving up wages and bringing back prosperity to America's former industrial heartlands.

How then do we understand the success of 'Trumpism'? Part of the explanation of the emergence and popularity of such racist populism is the effect of what Newton foresaw as the breakdown of the post-war settlement between capital and labour and the subsequent effect this would have on the racial settlement of the US economy. In the first instance, Newton's idea of the 'ruling circle' of capital enriching itself at the expense of the rest of society has become a stark reality. Since the hegemonic ascent of neo-liberalism in the late 1970s the lowest half of the US income distribution has effectively been cut out of the proceeds of economic growth. Between 1980 and 2014, whereas the average US national income per adult grew at $61 \%$, the average income of the bottom $50 \%$ of the income distribution stagnated at around $\$ 16,000$. During the same period, however, 
the top $10 \%$ and $1 \%$ of the income stream saw their incomes, predominantly through capital income, respectively rise by $121 \%$ and $205 \% .{ }^{36}$

This has resulted in astronomic levels of inequality whereby in 2012, even after the effects of The Great Recession, the top 1\%'s share of national income (19.3\%) reflected levels not seen since the height of the roaring twenties and the dawn of The Great Depression. To put this into perspective, the current income ratio between US adults in the top 1\% and the lowest $50 \%$ of income stream is $80: 1$. At the start of the neo-liberal period, this figure was on average $27: 1 .{ }^{37}$ This income and wealth inequality is compounded by the fact that the American democratic system has essentially become a plutocracy, whereby the US top income earners finance political parties and in turn influence government policy towards neo-liberal imperatives that favour their own interests. 38 Even the traditional bourgeois legitimation of democracy has been usurped by elite power. ${ }^{39}$ The neo-liberal period seeing a $5 \%$ fall in the population of the US middle class, as once affluent Americans fall below the median income, and the remaining middle class find their political influence eclipsed by the elite. ${ }^{40}$

As Newton perceived, this enrichment of the elite has taken place through processes of technological innovation and the expansion of the geography of capitalist production that have resulted in the decline of both US working and middle class economic security. Between 2000-2010 US industrial employment fell by 12 million to 29.6 million, largely as a result of offshoring and automation. This has seen US manufacturing employment fall from an all time high of 19.6 million in 1979 to 17.3 million in 2000 and 12.3 million in 2015. ${ }^{41}$ Throughout the 2000s, white-collar employment in higher level service jobs in finance, corporate IT, procurement, and human resources has also increasingly been automated or off-shored to destinations such as India. 42 The concurrent expansion of precarious, low-level service sector employment has not provided wages that match prior forms of blue or white-collar employment and has resulted in higher income inequality. ${ }^{43}$ On 
top of this, processes of state retrenchment, anti-unionisation and regressive taxation have burdened individuals with the costs of social subsides and made their wage demands further uncompetitive with often super-exploited workers in the Global South.

The decimation of the economic and political power of the US working and middle classes in the neo-liberal era should make it clear that what Newton thought would happen to the post-war settlement between capital and labour under reactionary intercommunalism has indeed happened. But the onset of neo-liberal globalization has also changed what Netwon saw as the link between the US economy and its wages of whiteness. As Newton's theorization of reactionary intercommunalism suggested, neo-liberalism has continued the racist exclusion of Black labour from the labour market, which has been a hallmark of the post-war US economy. Black unemployment has persistently hovered at a 2:1 ratio with white unemployment since the 1950s and spiked as high as 2.77 times that of white unemployment as the manufacturing sectors that employed disproportionate shares of Black labour went through neo-liberal restructuring in the late 1980s. ${ }^{44}$ The Black working class is now primarily located within the low-waged service sector, where Wal-Mart is the biggest employer of Black labour. ${ }^{45}$ The prison-industrial complex, which has seen the disproportionate mass incarceration of Black Americans and the subsequent use of cheap prison labour, furthers this racialized exploitation. ${ }^{46}$ This all takes place in a context in which thirty years of neoliberal policies have increasingly cut educational and social services across American cities, but financially supported the increasing militarisation of the policing of the Black community and other communities of colour. ${ }^{47}$

Despite the neo-liberal order perpetuating structural inequalities endured by Black Americans and other communities of colour, it has also, as Newton predicted, altered the wages of whiteness for whites in the US. As KeeangaYamahtaa Taylor points out, whilst the public face of poverty in the US is "Black", where explanations of the widespread poverty of non-white groups focus on racist tropes rather than the systemic problems of capitalism, the 
side effect of this narrative is that 'the hard times' that have befallen whites under neo-liberalism have been rendered 'almost invisible.' ${ }^{48}$ Due to a collapse in stable and well paying employment there has been a growth of poverty rates amongst working-class whites from $3 \%$ to $11 \%$ since the turn of century. As a result, the gap between white and Black poverty levels has decreased as whites find their income levels falling towards the levels of their Black counterparts. For example, one might expect that $65 \%$ of Black households now make only between $\$ 10,000$ to $\$ 43,000$ a year, but be concurrently surprised to learn that $43 \%$ of white households also now take home these relatively small amounts of income. ${ }^{49}$ This process was accelerated by the Financial Crisis of 2008, which now finds white wealth levels 31\% below what they would have been without The Great Recession that followed the crisis. ${ }^{50}$ And although non-white Americans find themselves over-represented in the ranks of the poor, the single largest ethnic group living in poverty in the US are whites. White Americans therefore now harbour a 25-year high pessimism about their future economic prospects, which is rooted in neo-liberalism's 'erosion of their economic situation'. 51

What the above reveals is that Newton's insight about the nature of neoliberal globalization and its disruption of the racialized settlement of the US economy has largely come to pass. The disappearance of the perceived privileges of the wages of whiteness for a large proportion of white America has in turn, as Newton believed, been refracted through a racial lens. Hochschild's ${ }^{52}$ ethnographic study in Louisiana (the second poorest US state) and its Republican Tea Party supporters turn towards Trumpism found exactly what Newton predicted forty years ago. As neo-liberal globalization has annihilated the socio-economic and political institutions that defined the wages of whiteness, white communities have become hostile to other, predominantly non-white, communities. What emerges from Hochschild's observations and interviews with right-wing activists and everyday citizens in Louisiana, is a story of white communities being 'left behind' by a neoliberal order that apparently favours everyone else other than themselves. A fact seemingly confirmed and compounded by the election of the first Black US President and his saving of Wall Street at the expense of Main Street. 
Hochschild found all of these grievances summed up in what she called the story of the 'line-cutters', a racist, misogynistic and xenophobic trope that she frequently encountered in Louisiana. Paraphrasing this trope, Hochschild outlines what amounts to nothing less than the mourning for the wages of whiteness that neo-liberalism has eradicated:

You're following the rules. They aren't. As they cut in, it feels like you are being moved back. How can they just do that? Who are they? Some are black. Through affirmative action plans, pushed by the federal government, they are being given preference for places in colleges and universities, apprenticeships, jobs, welfare payments, and free lunches, and they hold a certain secret place in people's minds, as we see below. Women, immigrants, refugees, public sector workers- where will it end? Your money is running through a liberal sympathy sieve you don't control or agree with. These are opportunities you'd have loved to have in your day-and either you should have had them when you were young or the young shouldn't be getting them now. It's not fair. 53

It is no surprise that modestly educated, white communities, whose jobs were most likely to be outsourced or automated, played a key part in Trump's electoral success across ex-industrial heartlands such as the Rust Belt. ${ }^{54}$ But if we recall Newton's predictions about the reconfiguration of middle-class power under reactionary intercommunalism, it should also be no surprise that it was the lower and upper white middle-class who were more likely to vote to MAGA. The average annual median income of a Trump voter was not $\$ 16,000$ but actually $\$ 72,000 .{ }^{55}$ Although winning the election on the back of an apparent anti-establishment, working-class populism, Trump was unable to secure a majority amongst the poorest voters or any ethnic grouping other than white Americans. This despite the fact that nonwhite Americans often make up the most exploited elements of the US working class and suffered disproportionately more economic hardship than whites during The Great Recession. ${ }^{56}$ 
Trumpism is therefore best seen as a promise to re-supply the wages of whiteness in in the absence of wages. The success of Trumpism is in this sense a racially regressive reaction to the effects of neo-liberal globalization's decimation of (white) working class and middle class economic and political power. This was confirmed at Trump's inaugural address:

This American carnage stops right here and stops right now.... We've made other countries rich while the wealth, strength, and confidence of our country has disappeared over the horizon. One by one, the factories shuttered and left our shores, with not even a thought about the millions upon millions of American workers left behind. The wealth of our middle class has been ripped from their homes and then redistributed across the entire world... From this moment on, it's going to be America First. ${ }^{57}$

This was also evident in the Trump campaign's merging of President Roosevelt's call to remember the 'forgotten man at the bottom of the economic pyramid' during the Great Depression with President Nixon's idea of the 'silent majority' who had endured the end of Jim Crow and the demands of Black Power in the late 1960s: ${ }^{58}$

I have visited the laid-off factory workers, and the communities crushed by our horrible and unfair trade deals. These are the forgotten men and women of our country. And they are forgotten, but they're not going to be forgotten long. People who work hard but no longer have a voice. I am your voice $!^{59}$

To MAGA was therefore to recall and restore the material, public and psychological wages of whiteness associated with an economically dynamic, but nevertheless racially segregated, post-war society that preceded the neo-liberal era:

I'm going to unleash American energy; I'm going to repeal and replace Obamacare; I'm going to appoint Justices to the Supreme Court who 
will follow the Constitution; I'm going to rebuild our depleted military and take care of our vets; I'm going to save your 2nd amendment; I'm going to stop illegal immigration and drugs coming into our country, and yes, we will build the wall [Mexico will pay]; and I'm going to renegotiate our disastrous trade deals, especially NAFTA - and we will only make great trade deals that put the American worker first. And we are going to put our miners and our steelworkers back to work. We will rebuild our roads, bridges, tunnels, highways, airports, schools and hospitals. American cars will travel the roads, American planes will soar in the skies, and American ships will patrol the seas. American steel will send new skyscrapers into the clouds. American hands will rebuild this nation - and American energy, harvested from American sources, will power this nation. American workers will be hired to do the job. We will put new American metal into the spine of this country. Jobs will return, incomes will rise, and new factories will come rushing back to our shores. We Will Make America Wealthy Again. ${ }^{60}$

This scenario reflects the reality of class and race that Newton foresaw in the 1970s. A vast number of white US citizens now find themselves in similar 'objective' conditions long experienced by their non-white counterparts both at home and abroad. At the mercy of the ruling circle of the $1 \%$, these groups have chosen, or have been convinced, to become the 'subjective enemies' of their non-white or foreign counterparts. When these factors are taken into consideration, Newton's assertion that imperialism's transition to reactionary intercommunalism would lead to demands for the wages of whiteness in the absence of wages, appears all too tragically prescient.

\section{Conclusion: dealing with the end of the wages of whiteness}

This article has attempted to retrieve Huey P. Newton's seemingly forgotten theorization of imperialism's transition to reactionary intercommunalism, not only to achieve some form of epistemic justice, but also because Newton's thought speaks urgently to our present. It has taken over forty 
years for the contours of a truly global capitalism to match up with Newton's proto-theorization of neo-liberal globalization. But Newton's theoretical prescience also centres on his appreciation of how such changes would be refracted through issues of race and whiteness that underpin the US state and its economy. In conclusion, I want to reflect on Newton's thought and why we should return to his ideas to understand the era of Trumpism. It is my contention that Newton's reflection on what the future may hold under reactionary intercommunalism may in fact be words about our present.

In a 1972 discussion with sociologists Franz Schurmann and Alberto Martinelli, Newton outlined his theory of intercommunalism and the future's likely political trajectory. Newton's main point to Schurmann and Martinelli was that the changes associated with reactionary intercommunalism, chiefly its technological displacement of jobs and the global spread of capitalist social relations, meant that Western imperialism's wages of whiteness, where imperial conquest led to a bargain between capital and the white working and middle classes in the metropole, were effectively over. Indeed, as Newton told an audience at Yale in 1971, he hoped white America would unite with '...those people who are already unemployable,' but whether this did or didn't happen that 'material existence will have changed. The proletarian will become the lumpen proletarian.' ${ }^{61}$ Newton's interview with Schurmann and Martinelli saw him declare that either the white US population would come to terms with this reality, and embrace the objective class relations between themselves and the vast array of humanity, or they would start on a path towards world war three:

'The people here have to realize that they live at the expense of the world, and this includes the workers. Either the people will oppose the reactionary circle for survival, for peace, or else they will go into the third world war. So our basic problem is educating and organizing...62 
Returning to Newton's ruminations on the impossibly of resupplying the wages of whiteness highlights how dangerous the death of the wages of whiteness may actually be for us all today. Trumpism's attempt to resupply the wages of whiteness through racism, nationalism and xenophobia, places humanity on a likely path towards war. Despite Trump's claim that 'jobs will return, incomes will rise, and new factories will come rushing back to our shores,' 63 Trumpism is unlikely to supply any jobs and material wages to its supporters because it is not designed or capable of doing so. Just as Du Bois highlighted at the start of the twentieth century that the wages of whiteness were designed by the elite to split class unity along racial lines, Trumpism's wages of whiteness appear designed to split class unity for elite ends at the start of the twenty-first century. Trump's economic plans, dubbed 'Trumponomics', essentially repackage neo-liberal 'trickle-down' policies with the promise of Keynesian stimulus. Trump has proposed massive infrastructure spending combined with huge tax cuts for the rich and corporations and further deregulation in the hope of generating investment and jobs. The 30-year track record of neo-liberalism has shown that these policies are unlikely to illicit investment in the economy and such a strategy seems incapable of addressing how technology, as Newton realised, will eliminate ever more jobs. ${ }^{64}$

As such, Trumpism will likely continue the processes of enriching elites and corporations at the expense of all members of the working and middle classes. ${ }^{65}$ This failure to supply the economic wages of whiteness will in turn likely be supplemented with the overtures to trade protectionism (Border Tax), racist and xenophobic polices such as (Muslim) travel bans, illegal migrant deportations, border wall building, and military actions that aim to supply the psychological aspects of the wages of whiteness. But this will simply be the supplying of the wages of whiteness in the absence of wages. There thus appears more chance that we shall see a race war in the US than any potential class struggle. However, the changes brought about by reactionary intercommunalism have also changed the nature of geopolitics and made such resurgent nationalism a more likely conduit for war 
on the international stage. The quest to remake the world in the American image, or rather in its interests, has enriched non-Western elites and empowered nations in the Global South in ways even Newton could not have foreseen. Although the 'neo-liberalism with southern characteristics' of the BRICS bloc does not yet mark an ideological and geo-political alternative to US and wider Western power, it does mark a world of increasing multipolarity. ${ }^{66}$ What chance that a trade war or imperial proxy war induced by Trumpism could lead to what Newton called the third world war?

Yet, Newton's thought also offers us a vision of an alternative approach to dealing with the end of the wages of whiteness and perhaps herein lays the true value of returning to Newton in the age of Trumpism. Newton's discussion with Schurmann and Martinelli revealed his frustration with the Western left's fixation with the 'factory as a phase that does not go through transformation.' 67 In Newton's eyes the left couldn't simply repeat the fantasy of returning to the post-war settlement between labour and capital. Not only was such a position unachievable due to the changes induced by reactionary intercommunalism, but also because such a position failed to see how the post-war era of embedded liberalism was itself a racialised imperial formation. Newton argued against nostalgic pleas for national forms of socialism, which had been used to imperially split humanity across the colour-line, and for a transnational politics he called 'Revolutionary intercommunalism.' 68

Revolutionary intercommunalism functioned off the recognition of the interconnected nature of the global economy and the need to deliver equality and justice for the entirety of the world's communities. Above all else, revolutionary intercommunalism rejected the idea that nationalist settlements, whether black or white or socialist, were the pathways towards liberation. In light of reactionary intercommunalism's global dimensions, Newton argued that only a global form of justice that would equally share the productivity and resource gains of technology would now suffice: 
In order for a revolution to occur in the United States you would have to have a redistribution of wealth not on a national or international level, but on an intercommunal level. Because how can we say that we have accomplished revolution if we redistribute the wealth just to people here in North America when the ruling circle itself is guilty of trespass de bonis asportatis. That is, they have taken away the goods of the people of the world, transported them to America and used them as their very own. ${ }^{69}$

Revolutionary intercommunalism saw the BPP create alliances with a plethora of social movements both within and beyond the US. These included the student-led anti-Vietnam War and Peace movements, Latino groups like the Young Lords Organisation and poor white American groups like the Young Patriots Organisation and 'peoples of world' pursuing nationhood, such the National Liberation Front in South Vietnam (NLF), the Mozambique Liberation Front (FRELIMO) and Palestinian Liberation Organisation (PLO). ${ }^{70}$ The aim of revolutionary intercommunalism was not only to create a united front of oppressed peoples against global capitalism, but also to create alternative forms of life to the capitalist way of life.

This ethos was exemplified in the BBP's 'survival programs', communitybased programs that were set-up and run by the Panthers and wider community to provide services such as free healthcare, free breakfasts for school children and free clothing for the Black community and other communities who had been excluded from the spoils of US capitalism. As Singh has suggested, the practices of the BPP's survival programs not only filled these gaps in welfare but also provided a 'projection of sovereignty' that rivalled the 'reality principle' of the US state. ${ }^{71}$ This entailed a practical deconstruction of the idea of state power (policing, education, welfare) that reimagined spaces and practices along new intercommunal lines of self-determination and democracy. Through attempting to disrupt class relations, racial segregation and gender roles, the BPP's survival programs also attempted to offer alternative ways of life, both 
institutionally and ideologically, to the racially divisive, class exploitative and gendered structures of capitalist society. ${ }^{72}$ The value of returning to Newton's thought today thus lays not only with his appreciation of how reactionary intercommunalism would be refracted through issues of race and whiteness, but also with how Newton's vision of revolutionary intercommunalism demands us to link the project of anti-imperialist solidarity with the creation of alternative intercommunal ways of life to capitalist society.

This especially pertinent given that Trumpism's critique of neo-liberal globalization ironically shares elements of the left's own social democratic critique of neo-liberal globalization. ${ }^{73}$ Although violently disagreeing on the means, both Trumpism and social democracy aim towards the end of taming global capitalism through reasserting national controls (whether this is through racist approaches to immigration or raising taxes) and alleviating economic insecurity through job creation (whether this is through deregulation and tax cuts or increased regulation and government spending). Newton's work on intercommunalism leads us to question the very categories of labour, nation, capital and democracy that underpin both Trumpism and contemporary social democratic politics. For example, Newton's theory of intercommunalism makes it clear that we must question the linking of wage labour and income in an environment where technology eliminates vast sways of jobs and labour markets are racially discriminatory. Moreover, we must ask this question with a global rather than solely a national inflection. Newton's thought thus demands that we consider a new politics that would create new institutions and ideologies that could serve and liberate communities both within and beyond the boundaries of nation states. Returning to Newton's theorization of reactionary intercommunalism, and his conclusion that both white supremacy and nationally bounded socialism were incapable of dealing with the contradictions of global capital, thus implores us to pursue a politics of intercommunal revolution rather than mere national reform. 
This may sound idealistic as we encounter the re-emergence of racist populism in the US and wider Western world. ${ }^{74}$ However, Newton's work reminds us that the contradictions of racial capitalism under the machinations of reactionary intercommunalism also offer the possibilities of hope as well as horror. Newton saw a chance for intercommunal solidarity and the creation of alternative forms of life because he believed the effects of the dwindling wages of whiteness now meant that the white populaces in the US were 'more ready to fight' than ever before. The key was to answer the questions '.... who shall he fight? Who is your enemy? Who is your friend?' Newton challenged the left in the West '...to show [that] the other unemployables are not the enemy.' 75 In our contemporary moment these words, and the anti-racist and anti-imperialist politics they commit us to, seem as urgent as the time they were first spoken.

\footnotetext{
Notes

${ }^{1}$ Newton 'Huey's Message at...' 16.

2 Brown, A Taste of Power ; Hilliard and Cole, This side of glory.

${ }^{3}$ See Heynen, 'Breaking the Bars...' for how Intercommunalism was itself challenged within the Black Panther Party.

${ }^{4}$ See Bloom and Joshua, Black Against Empire; Joseph, Waiting Til' the Midnight Hour; Singh, Black is a Country; Slate Black Power Beyond Borders. ${ }^{5}$ See Heynen, 'Breaking the Bars...' and Jefferies, Huey P. Newton..., for an exception to this rule.

${ }^{6}$ See Hobson, Imperialism; Luxemburg, The Accumulation of Capital; Lenin, Imperialism, The Highest Stage of Capitalism.

${ }^{7}$ For a view that challenges the idea that Marx neglected imperialism see Pradella, Globalization and the...

${ }^{8}$ Racial capitalism highlights how racialization and racism were integral blocks in the emergence of capitalism. The capitalist system is thus fused with and often dependent on forms of racialization and forms of domination based on such racialization. See Robinson, Black Marxism.

${ }^{9}$ Du Bois, The Souls of Black Folk, 3.

${ }^{10}$ Du Bois, The African Roots...

11 My argument here is not that these Marxists erased the relationship between race and class. Marx himself seems to have been aware of how racism could split class unity. See Marx 'Letter to Siegfried...' for his appreciation of how English and Irish working class conflict resembled: "that of the "poor whites" to the Negroes in the former slave states of the U.S.A.' Lenin was also aware of how the uneven nature of capitalist development had derailed Marx and Engels' conception of world revolution. Indeed, his work on imperialism further developed Engels' idea of a labour aristocracy splitting the global working class. Lenin was also
} 
aware of what he would call the 'Negro Question' and related the struggles of Black Americans to the struggle for national self-determination. However as Virdee (2017:10) highlights, Lenin, along with Luxemburg, 'consistently failed to come to terms with the corrosive effects of the racisms of imperialism on the European working class.' More specifically, Du Bois advances Marxist narrations of imperialism through highlighting how the aristocracy of labour that marked European imperialism was underpinned by a geo-political idea of white supremacy. For more on Du Bois' relationship to the work of Marx and Lenin and wider Marxist thought see Robinson, Black Marxism.

12 Du Bois, Darkwater, 17.

13 Roediger, The Wages of Whiteness. The idea of the wage of whiteness derives from Du Bois' reflections on the invention of white supremacy in US. In his monumental revision of the history of Reconstruction, Du Bois brings to the fore how white supremacy was invented in the South to curb the revolutionary potential of united Black and white labour after the abolition of slavery. This saw the ruling planter classes supplement the low wages of white labour with the 'public and psychological wage' of white supremacy after the end of the civil war. Shaping the economic, political and cultural institutions through the lens of white supremacy the ruling planter class were able to prevent workers with 'practically identical interests' from uniting after Reconstruction This in turn saw the rolling back of Reconstruction's gains for Black Americans with the onset of Jim Crow and the re-emergence of inter-racial conflict that masked the ruling class' economic exploitation of labour in its entirety. See Du Bois, Black Reconstruction, 573-574

14 Du Bois, Darkwater 24.

15 Ibid., 27. See Virdee (2014) for a history of how the wages of whiteness were facilitated by the socialist leaders of the European working class and how this lent such ideas a degree of authenticity and authority that would otherwise not have existed if they had come solely from above.

${ }^{16}$ Fanon, The Wretched of...

${ }^{17}$ Myrdal, The Challenge of ...299

18 Newton, Huey P. Newton Reader, 186-187.

19 Ibid., 188

20 Ibid., 256-258, 260, 265.

21 Ibid, 260.

22 Prashad, The Poorer Nations, 5.

23 Newton, Huey $P$. Newton Reader, 303

24 Ibid., 264-265.

25 Ibid., 302-303.

26 Ibid., 170-172.

27 Ibid., 259.

28 Ibid., 193, 263-264.

29 Ibid., 312.

30 lbid., 192-193.

31 Newton 'Huey's Message at...' 19.

32 Newton, Huey P. Newton Reader, 195. 
${ }^{33}$ Newton 'Interview with Huey, Franz Schurmann and Alberto Martinelli, ' 2.

34 For confirmation of Newton's preseicne about neo-liberal globalization see Harvey, A Short History of Neo-liberalism; Prashad, The Poorer Nations; Smith, Imperialism in the Twenty-First Century.

35 Trump 'Remarks on Foreign Policy...'

36 Roberts, 'Donald Trump and Capitalism's Next Crisis'; Roberts, The Long Depression, 137.

37 Roberts, 'Donald Trump and Capitalism's Next Crisis'

38 Gilens Affluence and Influence.

39 Gilens Affluence and Influence.

${ }^{40}$ Milanovic, Global Inequality, 196.

41 Smith, Imperialism in the Twenty-First Century, 103.

42 The Economist, 'On the Turn...'

${ }^{43}$ Milanovic, Global Inequality, 103-104.

44 Desilver 'Black Unemployment Rate'

45 Taylor, From \#BlackLivesMatter.., 183.

${ }^{46}$ Alexander, The New Jim Crow.

47 Wacquant, Punishing the Poor.

48 Taylor, From \#BlackLivesMatter.., 49.

49 Ibid., 211-12.

50 Burd-Sharps and Rasch, Impact of the US Housing Crisis.., 3.

51 Taylor, From \#BlackLivesMatter 211.

52 Hochschild, Strangers In Their Own Land.

53 Ibid., 137.

54 Silver, 'Education, Not Income, Predicted Who Would Vote For Trump.'

55 Kelly, 'Trump Says Go Back, We Say Fight Back.'

56 Kelly, 'Surveying Trumpland...' There were of course parts of communities of colour who voted for Trump. The key point here is that Whiteness is not necessarily embodied in white people but can be ideologically accepted by Black, Latino, Asian and other communities of colour. What these actors are doing is voting for a class project that necessarily only accepts them as an alibi for not being racist.

57 Trump, 'The Inaugural Address.'

58 Prashad, 'Voters Just Delivered...'

59 Trump 'Address Accepting the...'

60 Trump 'Remarks to the Economic...'

61 Newton, Huey P. Newton Reader, 193.

62 Newton, 'Interview with Huey...' Side III, pp.1.

63 Trump 'Remarks to the Economic...'

${ }^{64}$ Roberts, 'Donald Trump and Capitalism's Next Crisis'; Roberts, The Long Depression, 261-262.

65 The Trump administration's 2017-18 preliminary budget proposal confirms this, through its proposals scale down the size of discretionary domestic spending and increase discretionary defence spending. These cuts to domestic programmes directly target the very blue-collar workers Trump proclaimed to represent but are counterbalanced with increased spending on the projection of American power.

66 Prashad, The Poorer Nations, 10-12, 286-289. 
${ }^{67}$ Newton, 'Interview with Huey, Franz Schurmann and Alberto Martinelli, ' Side II, pp. 2.

${ }^{68}$ Newton, Huey P. Newton Reader, 171.

69 Ibid., 171-172.

70 Brown in Newton, To Die for the People, xviii-xix.

71 Singh, Black is a Country... 205-206.

72 This focus on new forms of life would not simply revolve around race and class issues but all facets of human existence such as sexuality and gender relations. Newton's ideas about this can be found in his essay 'The Women's Liberation and Gay Liberation Movement' see Huey P. Newton Reader, 157160. This essay not only outlines how the struggles of women and the gay liberation movement were key to ideas of revolutionary intercommunalism but also can be seen as an antecedent to intersectional analysis across race, class, gender and sexuality. Although Newton's ideas would fail to be taken on board in BPP practice, with the BPP suffering from institutionalised sexism and misogyny, it should also be noted that Newton was driven to take such an intervention and modify his own theory by the women who made up the rank and file of the Party. Indeed, revolutionary intercommunalism's focus on new forms of life therefore owes debts to the inherent Feminism of the BPP's women even if many of the BPP's men, including Newton at times, failed to uphold these ideals. For more on this issue see Spencer, The Revolution...

${ }^{73}$ For examples of social democratic forms of populism see Bernie Sanders in the US and Jeremy Corbyn leadership of The Labour Party in the UK.

74 My analysis here has centered on the US but as Milanovic's work highlights, see Global Inequality, rising inequality combined with respective factors such a migration, Islamophobia, and austerity has also seen an upsurge in right wing populist parties in countries such as the UK, France, Netherlands, Sweden, Denmark, Hungary and Austria. Although, it is beyond the scope of this paper to interrogate all of these cases individually the resurgence and popularity of racist nativism hints at a need to examine a wider displacement of the wages of whiteness across the Western world. For example, see Emejulu, A. 'On the Hideous Whiteness...' for an excellent take on BREXIT and whiteness. Moreover, it may also be useful to examine how the upsurge in right wing populist parties across the West is related to the rise of similar nationalisms across the Global South.

75 Newton, 'Interview with Huey..., ' Side III, pp. 1-2. 


\section{Bibliography}

Alexander, M. The New Jim Crow: Mass Incarceration in the Age of Colourblindness. New York: New Press. 2010.

Bloom, J. and Martin W.E. Black Against Empire: The History and Politics of the Black Panther Party. Berkeley: University of California Press. 2013.

Brown, E. A Taste of Power: A Black Woman's Story. New York: Pantheon Books. 1992.

Desilver, D. 'Black Unemployment rate is consistently twice that of whites.' Accessed 13/07/2017. www.pewresearch.org/fact-tank/2013/08/21/through-good-times-andbad-black-unemployment-is-consistently-double-that-of-whites/

Du Bois, W.E.B. The Souls of Black Folk: Essays and Sketches. Oxford University Press: Oxford. 2007 [1903].

Du Bois, W.E.B. 'The African Roots of the War' The Atlantic, May 1915. Accessed 13/01/2017. http: / / www.webdubois.org/dbAfricanRWar.html

Du Bois, W.E.B. Black Reconstruction in America. Oxford University Press: Oxford. 2014 [1933].

Du Bois, W.E.B. Darkwater: Voices from Within the Veil. London: Verso Books. 2016 [1920].

Emejulu, A. 'On the Hideous Whiteness Of Brexit: Let us be honest about our past and our present if we truly seek to dismantle white supremacy,' Verso Books Accessed 13/03/2017. www.versobooks.com/blogs/2733-on-the-hideous-whiteness-of-brexitlet-us-be-honest-about-our-past-and-our-present-if-we-truly-seek-todismantle-white-supremacy

Fanon, F. The Wretched of the Earth. New York: Grove Press. 2004 [1965].

Gilens, M. Affluence and Influence: Economic Inequality and Political Power in America. Princeton: Princeton University Press. 2012.

Harvey, D. A Short History of Neo-Liberalism. Oxford: Oxford University Press. 2005.

Heynen, N. 'Bending the Bars of Empire from Every Ghetto for Survival: The Black Panther Party's Radical Antihunger Politics of Social Reproduction and Scale', Annals of the Association of American Geographers, 99:2, 406-422. 2009.

Hilliard, D. This Side of Glory: The Autobiography of David Hilliard and the Story of the Black Panther Party. Boston: Little Brown. 1993.

Hochschild, A. Strangers In Their Own Land: Anger and Mourning on the American Right. New York: New Press. 2016.

Hobson, J. Imperialism: A Study. Ann Habour University of Michigan Press. 1965 [1902].

Jeffries, J.L. Huey P. Newton: The Radical Theorist. Jackson: University Press of Mississippi. 2002.

Joseph, P.E. Waiting Til' the Midnight Hour: A Narrative of Black Power in America. New York: Henry Holt and Company. 2006.

Kelly, R.G. 'Trump Says Go Back, We Say Fight Back,' Boston Review Accessed 20/12/2016.

http://bostonreview.net/forum/after-trump/robin-d-g-kelley-trumpsays-go-back-we-say-fight-back 
Kelly, R.G. 'Birth of a Nation: Surveying Trumpland with Cedric Robinson,' Boston Review. Accessed 07/03/2017. https: / / bostonreview.net/race-politics/robin-d-g-kelley-births-nation

Lenin, V. Imperialism: The Highest Stage of Capitalism. London: Penguin Books. 2010 [1917].

Luxemburg, R. The Accumulation of Capital. New York: Routledge. 2003 [1913].

Marx, K. 'Marx to Sigfrid Mayer and August Vogt in New York - 1870' Accessed 07/03/2017 https://www.marxists.org/archive/marx/works/1870/letters/70_04_09. $\underline{\mathrm{htm}}$

Millianovic, B. Global Inequality: A New Approach for the Age of Globalization. Cambridge, Massachusetts: The Belknap Press of Harvard University Press. 2016.

Myrdal, G. The Challenge of World Poverty. A World Anti-Poverty Programme Outline. New York: Pantheon Books. 1970.

Newton, H.P. 'Huey's Message at Boston College.' unpublished manuscript. Dr. Huey P. Newton Foundation Inc. collection, M0864. Dept. of Special Collections, Stanford University Libraries, Stanford, California. 1970.

Netwon, H.P. ' The technology

Newton, H.P. “'Interview with Huey, Franz Schurmann and Alberto Martinelli,' Unpublished manuscript. Dr. Huey P. Newton Foundation Inc. collection, M0864. Dept. of Special Collections, Stanford University Libraries, Stanford, California. 1972.

Newton, H.P. 'Merrit College Lecture Series 1 and 2,' Unpublished manuscript. Dr. Huey P. Newton Foundation Inc. collection, M0864. Dept. of Special Collections, Stanford University Libraries, Stanford, California. 1972.

Newton, H.P. The Huey P. Newton Reader. New York: Seven Stories Press. 2002.

Newton, H.P. To Die for the People. San Francisco: City Light Books. 2009 [1972].

Prashad, V. The Poorer Nations: A Possible History of the Global South. London: Verso Books. 2013.

Prashad V. 'Voters Just Delivered a Mandate to a Pack of Absolute Fiends and Monsters.'

Accessed 07/03/2017.

http://www.alternet.org/election-2016/voters-just-delivered-mandatepack-absolute-fiends-and-monsters

Pradella, L. Globalization and the Critique of Political Economy: New Insights from Marx's Writings. London: Routledge. 2015.

Roberts, M. The Long Depression. Chicago: Haymarket Books. 2016.

Roberts, M. 'Donald Trump and Capitalism's Next Crisis' Accessed 09/03/2017.

http://www.haymarketbooks.org/blogs/30-donald-trump-andcapitalism-s-next-crisis

Robinson, C. Black Marxism: The Making of the Black Radical Tradition. Chapel Hill: The University of North Carolina Press. 2000. 
Rodriguez, R. 'Long Live Third World Unity! Long Live Internationalism: Huey P. Newton's Revolutionary Intercommunalism,' Souls 8, no. 3 (2006): 119-141.

Silver, N. 'Education, Not Income, Predicted Who Would Vote For Trump' Accessed 28/01/2016.

http: / / fivethirtyeight.com/features/education-not-income-predictedwho-would-vote-for-trump/

Singh, N. Black is a Country: Race and the Unfinished Struggle for Democracy. Cambridge: Harvard University Press. 2004.

Slate, N. Black Power Beyond Borders: The Global Dimensions of the Black Power Movement. New York: Palgrave Macmillan. 2012.

Smith, J. Imperialism in the Twenty-First Century: Globalization, SuperExploitation and Capitalism's Final Crisis. New York: Monthly Review Press. 2016.

Spencer, R. The Revolution Has Come: Black Power, Gender and the Black Panther Party in Oakland. Durham: Duke University Press. 2016.

Taylor, K.Y. From \#BlackLivesMatter to Black Liberation. Chicago: Haymarket Books. 2016.

The Economist, 'On the Turn; India's Outsourcing Business' Jan 19th 2013: S.13S.16.

Trump, D.J. 'Remarks on Foreign Policy at National Press Club in Washington, DC April 27 th 2016' Accessed 02/07/2017. http: / / www.presidency.ucsb.edu/ws/index.php?pid=117813

Trump, D.J. 'Address Accepting the Presidential Nomination July 21 ${ }^{\text {st }} 2016$ ' Accessed 02/07/2017. http: / / www.presidency.ucsb.edu/ws/index.php?pid=117935

Trump, D.J. 'Remarks to the New York Economic Club or New York September $15^{\text {th }} 2016^{\prime}$ Accessed 02/07/2017. http: / / www.presidency.ucsb.edu/ws/index.php?pid=117935

Trump, D.J. 'The Inaugural Address' Accessed 02/07/2017. http: / / www.presidency.ucsb.edu/ws/index.php?pid=119209

Virdee, S. Racism, Class and the Racialized Outsider. Basingstoke: Palgrave. 2014.

Virdee, S. 'The second sight of racialised outsiders in the imperialist core.' Third World Quarterly. 2017. DOI: 10.1080/01436597.2017.1328274

Wacquant, L. Punishing the Poor: The Neo-Liberal Government of Social Security. Durham: Duke University Press. 2009. 